\title{
Effects of Dissolved Organic Matter on Uptake and Translocation of Lead in Brassica chinensis and Potential Health Risk of $\mathrm{Pb}$
}

\author{
Renying $\mathrm{Li}^{1,2,3, *}$, Zhigao Zhou ${ }^{2}$, Xiaojin Xie ${ }^{1}$, Yingxue $\mathrm{Li}^{1}$, Yaohong Zhang ${ }^{1}$ and Xianghua $\mathrm{Xu}^{1}$ \\ 1 Jiangsu Key Laboratory of Agricultural Meteorology, Nanjing University of Information Science \& \\ Technology, Nanjing 210044, China; xxj_200210@nuist.edu.cn (X.X.); lyxue@nuist.edu.cn (Y.L.); \\ yhzhang@nuist.edu.cn (Y.Z.); xianghua_xu@163.com (X.X.) \\ 2 Key Laboratory of Soil Environment and Pollution Remediation, Institute of Soil Science, \\ Chinese Academy of Sciences, Nanjing 210008, China; zgzhou@issas.ac.cn \\ 3 School of Chemical Engineering and Energy, Zhengzhou University, Zhengzhou 450001, China \\ * Correspondence: ryli2005@nuist.edu.cn; Tel.: +86-25-5869-9784
}

Academic Editor: Howards W. Mielke

Received: 4 May 2016; Accepted: 21 June 2016; Published: 8 July 2016

\begin{abstract}
Dissolved organic matter (DOM) can affect the bioavailability of heavy metals in soil, especially in soils used for vegetable production, where intensive organic fertilization is applied. The present study examined the effects of DOM derived from commercial organic fertilizers (COF), cow manure $(\mathrm{COM})$ and chicken manure $(\mathrm{CHM})$, on uptake and translocation of lead $(\mathrm{Pb})$ in Brassica chinensis in a pot experiment. The results indicate that DOM derived from $\mathrm{CHM}\left(\mathrm{DOM}_{\mathrm{CHM}}\right)$ significantly increased $\mathrm{Pb}$ concentrations in roots of B. chinensis $(p<0.05)$. By contrast, there was no significant increase in shoot $\mathrm{Pb}$ concentration for all the DOM treatments except the high $\mathrm{DOM}_{\mathrm{CHM}}$ treatment in the soil with $800 \mathrm{mg} \cdot \mathrm{kg}^{-1} \mathrm{~Pb}$. Consistent with the $\mathrm{Pb}$ concentrations in shoots, translocation factor of $\mathrm{Pb}$ from soil to shoot and specific lead uptake (SLU) by B. chinensis were significantly increased for the high $\mathrm{DOM}_{\mathrm{CHM}}$ treatment in the high $\mathrm{Pb}$ soil, but not for other $\mathrm{DOM}$ treatments. Based on the results of this study, the application of DOM to the soil with $800 \mathrm{mg} \cdot \mathrm{kg}^{-1}$ $\mathrm{Pb}$ could result in an increase in total $\mathrm{Pb}$ annually ingested by the inhabitants of Nanjing City in the range of 2018-9640 kg, with the highest estimates resulting from the high $\mathrm{DOM}_{\mathrm{CHM}}$ treatment. This study suggests the risk may rise under some conditions as indicated in the high $\mathrm{DOM}_{\mathrm{CHM}}$ treatment and high $\mathrm{Pb}$ pollution level.
\end{abstract}

Keywords: Brassica chinensis; dissolved organic matter; lead; uptake; translocation

\section{Introduction}

Pollution of lead $(\mathrm{Pb})$ has raised a great concern on the health of human and other organisms because of its toxicity and persistence in the environment. Previous studies have shown that $\mathrm{Pb}$ can induce various morphological, physiological and biochemical abnormalities in plants such as decrease in seed germination, plant growth and chlorophyll production, and upsets in mineral nutrition and water balance [1-3].

The bioavailability of $\mathrm{Pb}$ to plants is closely related to its chemical speciation in soil [4-6]. Dissolved organic matter (DOM), through forming complexes with $\mathrm{Pb}$, plays a significant role in $\mathrm{Pb}$ speciation in soil and thus its availability to plants [7-9]. Khan et al. [9] observed that $\mathrm{Pb}$ and cadmium $(\mathrm{Cd})$ concentrations in wheat were increased when humic acid-rich sewage was irrigated, and concluded that humic acids enhanced the availability of $\mathrm{Pb}$ and $\mathrm{Cd}$ to plants.

Domestic animal manure is an important source of organic fertilizer for agricultural soils, particularly in intensive vegetable production areas, because of its ability to enhance vegetable growth 
and production through providing nutrients and improving soil structure [10,11]. On the other hand, animal manure application can increase DOM concentration in soils, which may escalate the risk of heavy metal pollution due to its positive effect on solubility and mobility (i.e., bioavailability) of heavy metals in soils $[7,9]$. DOM is a complex mixture, and its composition, concentration and then effect on bioavailability of heavy metals may depend largely on its source [12,13]. Cow and chicken manures are two of the main forms of organic fertilizers applied to the soils used to grow vegetables [14]. Commercial organic matter is also widely applied to soils under various cropping systems including vegetable growing [15]. Traditionally, these organic fertilizers are applied at rates based on their $\mathrm{N}$ (or P) content and prescribed percentage to total $\mathrm{N}$ (or P) input as fertilizers, and usually at larger rates for vegetable-growing soils than for grain crops-growing soils [16]. However, there is little information on the risk of enhanced DOM due to higher application rates of organic fertilizers in vegetable-growing soils, which are lightly and moderately polluted by $\mathrm{Pb}$. In practice, these organic fertilizers are applied to vegetable soils based on their prescribed $\mathrm{N}$ or $\mathrm{P}$ contribution. Considering their significant difference in DOM release from similar application rates, it is important to understand the effects of DOM derived from these widely-used organic fertilizers at concentrations likely occurring in the field on $\mathrm{Pb}$ accumulation in vegetables.

Soil-to-plant translocation factor is an index for evaluating the translocation potential of a metal from soil to plant [17]. The translocation factor is generally defined as the ratio of the metal concentration in the plant to the total metal concentration in the soil [17]. Some studies have indicated that the translocation factor of heavy metals depends on plant species $[17,18]$, heavy metal concentration in soil [19] and environmental conditions [20]. As mentioned above, DOM can affect soil $\mathrm{Pb}$ availability to plants. It is still unclear how the translocation factor of $\mathrm{Pb}$ may vary with $\mathrm{DOM}$ source and concentration in vegetable-grown soils.

In the present study, we used Brassica chinensis in pot experiment because it is one of the primary vegetables consumed in China. The objectives of this study were to: (1) investigate the effect of DOM of three widely-used organic fertilizers at different concentrations likely occurring in vegetable-grown soils on $\mathrm{Pb}$ accumulation and uptake in B. chinensis; and (2) assess the effect of DOM of various sources at different concentrations on the translocation of $\mathrm{Pb}$ from soil to B. chinensis. In addition, we discussed the potential risk of elevated $\mathrm{Pb}$ concentration in $B$. chinensis due to enhanced $\mathrm{DOM}$ in vegetable-grown soils as suggested in this study.

\section{Materials and Methods}

\subsection{Soil and DOM Preparation}

The soil used in this study was collected from a suburb area of the city of Nanjing, Jiangsu Province, China. After being transported to the laboratory, the soil was air-dried, sieved $(<5 \mathrm{~mm})$ and homogenized for a pot experiment. Subsamples were ground through a $10(<2 \mathrm{~mm})$ and 100 $(<0.149 \mathrm{~mm})$ mesh sieves for analyzing its chemical and physical properties. Selected soil properties were analyzed according to the methods recommended by the Soil Science Society of China [21]. Soil $\mathrm{pH}$ was measured by $\mathrm{pH}$ meter using a 1:2.5 soil to water ratio. Organic matter content was determined by the wet combustion method [22]. Total nitrogen $(\mathrm{N})$ was determined by the Kjeldahl method. Total phosphorus $(\mathrm{P})$ and total potassium $(\mathrm{K})$ were measured by the colorimetric molybdenum blue method and flame photometer (Shangyi 6400A), respectively, after the soil subsample $(<0.149 \mathrm{~mm}$ ) was digested by the three-acid ( $\mathrm{HF}-\mathrm{HClO}_{4}-\mathrm{HNO}_{3}$ ) method. Total $\mathrm{Pb}, \mathrm{Cd}, \mathrm{Cr}, \mathrm{Cu}$ and $\mathrm{Zn}$ were measured by ICP-AES (Optima 8000) using the same digest. Clay content was determined using a laser particle size analyzer (LS 13320). The $\mathrm{pH}$ of the soil was 6.81 . The soil contained $14.0 \mathrm{mg} \cdot \mathrm{g}^{-1}$ organic matter, $0.92 \mathrm{mg} \cdot \mathrm{g}^{-1}$ total $\mathrm{N}, 0.58 \mathrm{mg} \cdot \mathrm{g}^{-1}$ total $\mathrm{P}, 17.4 \mathrm{mg} \cdot \mathrm{g}^{-1}$ total $\mathrm{K}$, and $15.2 \%$ clay $(v / v)$. Total $\mathrm{Pb}, \mathrm{Cd}, \mathrm{Cr}, \mathrm{Cu}$ and $\mathrm{Zn}$ concentrations in the soil were $7.15,1.40,33.33,13.66$ and $69.51 \mathrm{mg} \cdot \mathrm{kg}^{-1}$, respectively.

Samples of commercial organic fertilizer (COF), cow manure (COM) and chicken manure (CHM) were collected from a commercial farm in the suburb of Nanjing. The organic matter samples were 
air-dried, ground and sieved $(<0.5 \mathrm{~mm})$. DOM samples were prepared using a modified method reported by Barricuso et al. [23]. Specifically, each of the organic matter samples was first shaken for $8 \mathrm{~h}$ at an organic matter-to-water ratio of 1:20 $(w / v)$, then incubated aerobically for one week at $25{ }^{\circ} \mathrm{C}$, and, finally, centrifuged for $30 \mathrm{~min}(4500 \mathrm{r} / \mathrm{min})$ and filtered through a $0.45 \mu \mathrm{m}$ membrane. The resulting filtrates were considered as the DOM samples of various sources, which were used in this study. The $\mathrm{pH}$ of the DOM samples was measured by $\mathrm{pH}$ meter. Their total organic carbon (TOC) concentrations were determined using a liquid $\mathrm{C} / \mathrm{N}$ analyzer (Vario Toc). Total $\mathrm{Pb}, \mathrm{Cd}, \mathrm{Cr}, \mathrm{Cu}$ and $\mathrm{Zn}$ concentrations of the DOM samples were determined by ICP-AES (Optima 8000). The basic physicochemical properties of the DOM samples are shown in Table 1.

Table 1. Physicochemical properties of dissolved organic matter (DOM) from different sources.

\begin{tabular}{cccccccc}
\hline $\begin{array}{c}\text { Source of } \\
\text { DOM }\end{array}$ & $\mathbf{p H}$ & $\begin{array}{c}\text { TOC } \\
\mathbf{m g} \cdot \mathbf{L}^{-\mathbf{1}}\end{array}$ & $\begin{array}{c}\text { Total } \mathbf{~ P b} \\
\mathbf{m g} \cdot \mathbf{L}^{-\mathbf{1}}\end{array}$ & $\begin{array}{c}\text { Total Cd } \\
\mathbf{m g} \cdot \mathbf{L}^{-\mathbf{1}}\end{array}$ & $\begin{array}{c}\text { Total Cr } \\
\mathbf{m g} \cdot \mathbf{L}^{-\mathbf{1}}\end{array}$ & $\begin{array}{c}\text { Total Cu } \\
\mathbf{m g} \cdot \mathbf{L}^{-\mathbf{1}}\end{array}$ & $\begin{array}{c}\text { Total Zn } \\
\mathbf{m g} \cdot \mathbf{L}^{-\mathbf{1}}\end{array}$ \\
\hline COF & 7.21 & 69 & nd & nd & nd & 0.01 & 0.03 \\
COM & 7.16 & 482 & nd & nd & nd & 0.02 & 0.09 \\
CHM & 7.19 & 6605 & nd & nd & 0.02 & 0.03 & 2.29 \\
\hline
\end{tabular}

nd: stands for concentration below the detection limit; DOM: represents dissolved organic matter; COF: commercial organic fertilizer; COM: cow manure; CHM: chicken manure.

\subsection{Experimental Setup}

A pot experiment was conducted in a greenhouse with a temperature ranging between 20 and $30{ }^{\circ} \mathrm{C}$ in a day. Three levels of $\mathrm{Pb}$ addition: 0 (Pb0), $100(\mathrm{~Pb} 100)$ and $800 \mathrm{mg} \mathrm{Pb} \cdot \mathrm{kg}^{-1}$ soil $(\mathrm{Pb} 800)$, and three DOM samples prepared from COF, COM and CHM (named as DOM $\mathrm{COF}, \mathrm{DOM}_{\mathrm{COM}}$ and $\mathrm{DOM}_{\mathrm{CHM}}$ ) each with two dosages (low: $100 \mathrm{~mL}$ and high: $500 \mathrm{~mL}$ ) were used in the pot experiment. The DOM-free treatment (without addition of DOM) at each Pb level was the common blank control for all the DOM treatments at the same soil $\mathrm{Pb}$ level. Each treatment was replicated three times. For each $\mathrm{Pb}$-added treatment (pot), a required aliquot of $\mathrm{Pb}$ solution $\left(\mathrm{as} \mathrm{Pb}\left(\mathrm{NO}_{3}\right)_{2}\right)$ was added to $1.2 \mathrm{~kg}$ of soil, mixed thoroughly, watered to $60 \%$ field water holding capacity and left at room temperature for two weeks. In addition to spiked $\mathrm{Pb}$, basic fertilizers including $150 \mathrm{mg} \cdot \mathrm{N} \cdot \mathrm{kg}^{-1}$ soil as $\left(\mathrm{NH}_{4}\right)_{2} \mathrm{SO}_{4}$, $100 \mathrm{mg} \cdot \mathrm{P}_{2} \mathrm{O}_{5} \cdot \mathrm{kg}^{-1}$ soil as $\mathrm{KH}_{2} \mathrm{PO}_{4}$, and $150 \mathrm{mg} \cdot \mathrm{K}_{2} \mathrm{O} \cdot \mathrm{kg}^{-1}$ soil as $\mathrm{K}_{2} \mathrm{SO}_{4}$ and $\mathrm{KH}_{2} \mathrm{PO}_{4}$, were mixed thoroughly with the soil in each pot.

\subsection{Plant Culture, Sample Collection and Analysis}

Seeds of B. chinensis were soaked overnight in distilled water and then placed on a wetted filter paper at $30{ }^{\circ} \mathrm{C}$ in an incubator. After two days, four seeds were transplanted into each pot, which were thinned to two seedlings in each pot after coming out. After one month of growth, either $100 \mathrm{or} 500 \mathrm{~mL}$ of DOM samples prepared from the three sources were added to the pots except the DOM-free controls.

During the growth of $B$. chinensis, distilled water was added and soil moisture was adjusted to $60 \%$ of its field water capacity by weighing the loaded pots. Fifty days after transplantation, the plants were harvested, separated into shoots and roots, rinsed with tap water and then distilled water, dried at $70{ }^{\circ} \mathrm{C}$ for $48 \mathrm{~h}$, and weighed. Dried plant samples were ground and digested using $\mathrm{HNO}_{3}$ and $\mathrm{HClO}_{4}[11,21] . \mathrm{Pb}$ in the digests was determined by ICP-AES (Optima 8000). A reagent blank and standard reference plant material (GBW07603 from the Chinese National Center for Standard Materials) were included in the analysis for the analytical quality control. 


\subsection{The Soil-to-Plant Translocation Factor of Pb and Specific Lead Uptake (SLU)}

The ability of $B$. chinensis to translocate and take up $\mathrm{Pb}$ was assessed using the translocation factor (TF) [17] and specific lead uptake (SLU) [24] as follows,

$$
\begin{gathered}
T F=\frac{[\mathrm{Pb}]_{\text {shoot }}}{[\mathrm{Pb}]_{\text {soil }}} \\
\text { SLU }=\frac{[\mathrm{Pb}]_{\text {root }} \times \text { Biomass }_{\text {root }}+[\mathrm{Pb}]_{\text {shoot }} \times \text { Biomass }_{\text {shoot }}}{\text { Biomass }_{\text {root }}}
\end{gathered}
$$

where $[\mathrm{Pb}]_{\text {shoot}},[\mathrm{Pb}]_{\text {root }}$ and $[\mathrm{Pb}]_{\text {soil }}$ are the concentrations of $\mathrm{Pb}$ in shoots, roots and soil, respectively; and Biomass shoot $_{\text {and Biomass }}$ root are the dry weights of shoots and roots of B. chinensis, respectively.

\subsection{Potential Health Risk of $\mathrm{Pb}$}

To estimate the potential health risk posed by the higher concentrations of $\mathrm{Pb}$ resulting from the addition of $\mathrm{DOM}$ to the soil, the increase of the amount of $\mathrm{Pb}$ ingested by the population was calculated using the following Equation (1), taking Nanjing City (Jiangsu Province, China) as an example, based on the data from the soil with $800 \mathrm{mg} \cdot \mathrm{kg}^{-1} \mathrm{~Pb}$ added in the present study.

$$
I_{a}=D_{i} \times C \times E_{t} \times P \times I_{p}
$$

$I_{a}$ is the increase of the amount of $\mathrm{Pb}$ ingested by the population $(\mathrm{kg}) ; D_{i}$ is amount of $B$. chinensis (g. person ${ }^{-1}$. day $^{-1}$ ) consumed; $C$ is the $\mathrm{Pb}$ concentration in the edible part of $B$. chinensis grown in soil with $800 \mathrm{mg} \cdot \mathrm{kg}^{-1} \mathrm{~Pb}\left(7.42 \mathrm{mg} \cdot \mathrm{kg}^{-1}\right) ; E_{t}$ is the exposure time ( 365 days); $P$ is population ( 8.24 million) of Nanjing City in 2015; $I_{p}$ is the percent increase in $\mathrm{Pb}$ concentration in the edible parts of the vegetable when DOM is added to the soil (\%), compared with DOM-free treatment.

\subsection{Statistical Analysis}

Data are expressed as means \pm standard error (SE). The Data were analyzed with a one-way analysis of variance (ANOVA) approach, using SPSS software program (SPSS, Inc., Chicago version 19.0, Chicago, IL, USA). Differences among the treatments were tested using Least Significant Difference (LSD) test.

\section{Results}

\subsection{Plant Growth}

There was no significant difference among the biomass (shoots or roots) of B. chinensis grown in the soils at different $\mathrm{Pb}$ levels with no DOM addition (the controls at the first row in Table 2), indicating that the addition of 100 or $800 \mathrm{mg} \cdot \mathrm{kg}^{-1} \mathrm{~Pb}$ to the soil had no toxic effect on the growth of B. chinensis (Table 2). The addition of DOM except the high $\mathrm{DOM}_{\mathrm{CHM}}$ treatment in the $\mathrm{Pb} 800$ soil had no significant effect on the biomass of B. chinensis. Compared with the Pb800 control, the biomass of the high $\mathrm{DOM}_{\mathrm{CHM}}$ treatment significantly decreased by $42.6 \%$ for shoots and $81.8 \%$ for roots in the $\mathrm{Pb} 800$ soil, respectively $(p<0.05)$. 
Table 2. Dry biomass of shoots and roots of Brassica chinensis treated with varying amounts of DOM from different sources at different soil $\mathrm{Pb}$ levels.

\begin{tabular}{|c|c|c|c|c|c|c|c|}
\hline \multirow{2}{*}{$\begin{array}{l}\text { DOM } \\
\text { Source }\end{array}$} & \multirow{2}{*}{$\begin{array}{c}\text { DOM } \\
\text { Dosage }\end{array}$} & \multicolumn{3}{|c|}{ Shoot Biomass (g) } & \multicolumn{3}{|c|}{ Root Biomass (g) } \\
\hline & & Pb0 & Pb100 & $\mathrm{Pb800}$ & Pb0 & Pb100 & $\mathrm{Pb} 800$ \\
\hline control & 0 & $3.39 \pm 0.24 \mathrm{a}^{\mathrm{a}}$ & $3.59 \pm 0.33 \mathrm{a}^{\mathrm{a}}$ & $3.29 \pm 0.43 \mathrm{a}^{\mathrm{a}}$ & $0.10 \pm 0.02 \mathrm{a}^{\mathrm{a}}$ & $0.15 \pm 0.03 \mathrm{a}^{\mathrm{a}}$ & $0.11 \pm 0.02 \mathrm{a}^{\mathrm{a}}$ \\
\hline \multirow{2}{*}{$\mathrm{COF}$} & Low & $3.60 \pm 0.49 a^{a}$ & $3.84 \pm 0.30 a^{a}$ & $3.31 \pm 0.17 \mathrm{a}^{\mathrm{a}}$ & $0.13 \pm 0.04 \mathrm{a}^{\mathrm{a}}$ & $0.12 \pm 0.02 \mathrm{a}^{\mathrm{a}}$ & $0.08 \pm 0.02 \mathrm{a}^{\mathrm{a}}$ \\
\hline & High & $3.67 \pm 0.27 \mathrm{a}^{\mathrm{a}}$ & $3.65 \pm 0.09 \mathrm{a}^{\mathrm{a}}$ & $3.60 \pm 0.23 \mathrm{a}^{\mathrm{a}}$ & $0.12 \pm 0.02 \mathrm{a}^{\mathrm{a}}$ & $0.11 \pm 0.01 \mathrm{a}^{\mathrm{a}}$ & $0.12 \pm 0.01 \mathrm{a}^{\mathrm{a}}$ \\
\hline \multirow{2}{*}{$\mathrm{COM}$} & Low & $3.46 \pm 0.13 \mathrm{a}^{\mathrm{a}}$ & $3.82 \pm 0.42 \mathrm{a}^{\mathrm{a}}$ & $4.07 \pm 0.69 \mathrm{a}^{\mathrm{a}}$ & $0.11 \pm 0.01 \mathrm{a}^{\mathrm{a}}$ & $0.15 \pm 0.04 \mathrm{a}^{\mathrm{a}}$ & $0.12 \pm 0.03 \mathrm{a}^{\mathrm{a}}$ \\
\hline & High & $3.61 \pm 0.36 \mathrm{a}^{\mathrm{a}}$ & $4.06 \pm 0.56 \mathrm{a}^{\mathrm{a}}$ & $3.54 \pm 0.18 \mathrm{a}^{\mathrm{a}}$ & $0.12 \pm 0.03 \mathrm{a}^{\mathrm{a}}$ & $0.18 \pm 0.04 a^{a}$ & $0.11 \pm 0.01 \mathrm{a}^{\mathrm{a}}$ \\
\hline \multirow{2}{*}{$\mathrm{CHM}$} & Low & $3.56 \pm 0.21 a^{a}$ & $4.01 \pm 1.04 \mathrm{a}^{\mathrm{a}}$ & $4.09 \pm 0.39 \mathrm{a}^{\mathrm{a}}$ & $0.09 \pm 0.02 \mathrm{a}^{\mathrm{a}}$ & $0.11 \pm 0.06 \mathrm{a}^{\mathrm{a}}$ & $0.13 \pm 0.01 \mathrm{a}^{\mathrm{a}}$ \\
\hline & High & $3.78 \pm 0.71 \mathrm{a}^{\mathrm{a}}$ & $4.46 \pm 0.74 \mathrm{a}^{\mathrm{a}}$ & $1.89 \pm 0.35 b^{b}$ & $0.09 \pm 0.03 \mathrm{a}^{\mathrm{a}}$ & $0.14 \pm 0.05 \mathrm{a}^{\mathrm{a}}$ & $0.02 \pm 0.01 b^{b}$ \\
\hline
\end{tabular}

DOM: stands for dissolved organic matter; COF: represents commercial organic fertilizer; COM: cow manure: CHM: chicken manure; $\mathrm{Pb} 0, \mathrm{~Pb} 100$ and $\mathrm{Pb} 800$ denote the pot soils to which 0,100 and $800 \mathrm{mg} \cdot \mathrm{kg}^{-1} \mathrm{~Pb}$ were added, respectively. The different superscript letters in the same row indicate significant difference in shoot or root biomass $(p<0.05)$ among the soil Pb levels according to the LSD (Least Significant Difference) test. The different letters following the data in the same column indicate significant difference in shoot or root biomass $(p<0.05)$ among DOM treatments according to the LSD test. Data are means \pm SE $(n=3)$.

\subsection{Pb Concentrations inShoots and Roots}

The application of DOM extracts from COF, COM and CHM affected differentially (varying with $\mathrm{DOM}$ source and dosage, and soil $\mathrm{Pb}$ level) $\mathrm{Pb}$ concentrations in shoots and roots of $B$. chinensis (Table 3). Compared with the control, root $\mathrm{Pb}$ concentration was significantly increased in low and high $\mathrm{DOM}_{\mathrm{CHM}}$ treatments at the three soil $\mathrm{Pb}$ levels, with statistical difference for all the $\mathrm{DOM}_{\mathrm{CHM}}$ treatments except the low DOM $\mathrm{CHM}_{\mathrm{C}}$ treatment at Pb800 level $(p<0.05)$. For DOM $\mathrm{COF}_{\mathrm{C}}$ and $\mathrm{DOM}_{\mathrm{COM}}$, root $\mathrm{Pb}$ concentration was significantly increased in the high-dosage treatments but not in the low-dosage ones at the $\mathrm{Pb} 0$ level compared to the control at the $\mathrm{Pb} 0$ level, and was not significantly different between the DOM treatments and the control at the Pb100 and Pb800 levels, expect for high $\mathrm{DOM}_{\mathrm{COM}}$ dosage treatment. A significant increase in shoot $\mathrm{Pb}$ concentration was observed for DOM treatments at the Pb800 level compared to the control. There was no significant difference in shoot $\mathrm{Pb}$ concentration between other DOM treatments and the corresponding controls at the $\mathrm{Pb} 0$ and $\mathrm{Pb} 100$ soil. As expected, $\mathrm{Pb}$ concentrations in shoots or roots increased with increasing soil $\mathrm{Pb}$ level for any of the three DOM sources.

Table 3. $\mathrm{Pb}$ concentrations in shoots and roots of Brassica chinensis treated with varying amounts of DOM from different sources at different soil $\mathrm{Pb}$ levels.

\begin{tabular}{|c|c|c|c|c|c|c|c|}
\hline \multirow{2}{*}{$\begin{array}{c}\text { DOM } \\
\text { Source }\end{array}$} & \multirow{2}{*}{$\begin{array}{l}\text { DOM } \\
\text { Dosage }\end{array}$} & \multicolumn{3}{|c|}{$\mathrm{Pb}$ Concentration in Shoots $\left(\mathrm{mg} \cdot \mathrm{kg}^{-1}\right)$} & \multicolumn{3}{|c|}{$\mathrm{Pb}$ Concentration in Roots $\left(\mathrm{mg} \cdot \mathrm{kg}^{-1}\right)$} \\
\hline & & $\mathrm{Pb0}$ & Pb100 & $\mathrm{Pb} 800$ & Pb0 & Pb100 & $\mathrm{Pb} 800$ \\
\hline control & 0 & $4.05 \pm 0.31 \mathrm{a}^{\mathrm{c}}$ & $6.73 \pm 0.26 \mathrm{a}^{\mathrm{b}}$ & $7.42 \pm 1.33 c^{a}$ & $2.13 \pm 0.17 b^{c}$ & $24.99 \pm 1.50 \mathrm{bc}^{\mathrm{b}}$ & $467.37 \pm 23.35 b^{a}$ \\
\hline \multirow{2}{*}{$\mathrm{COF}$} & Low & $4.62 \pm 1.78 \mathrm{a}^{\mathrm{b}}$ & $6.76 \pm 0.31 \mathrm{a}^{\mathrm{b}}$ & $10.72 \pm 1.43 b^{a}$ & $2.00 \pm 0.19 \mathrm{~b}^{\mathrm{c}}$ & $25.58 \pm 0.83 b^{b}$ & $442.16 \pm 15.88 b c^{a}$ \\
\hline & High & $3.87 \pm 0.59 \mathrm{a}^{\mathrm{c}}$ & $8.56 \pm 1.72 \mathrm{a}^{\mathrm{b}}$ & $13.28 \pm 1.06 \mathrm{~b}^{\mathrm{a}}$ & $8.78 \pm 1.24 \mathrm{a}^{\mathrm{c}}$ & $23.97 \pm 1.63 b c^{b}$ & $437.54 \pm 27.72 b^{a}{ }^{a}$ \\
\hline \multirow{2}{*}{$\mathrm{COM}$} & Low & $3.72 \pm 0.74 \mathrm{a}^{\mathrm{b}}$ & $7.36 \pm 0.47 \mathrm{a}^{\mathrm{a}}$ & $9.66 \pm 1.13 b c^{a}$ & $2.66 \pm 0.45 b^{c}$ & $25.08 \pm 0.65 \mathrm{~b}^{\mathrm{b}}$ & $449.50 \pm 29.88 b c^{a}$ \\
\hline & High & $3.88 \pm 0.22 \mathrm{a}^{\mathrm{c}}$ & $7.70 \pm 1.31 \mathrm{a}^{\mathrm{b}}$ & $11.79 \pm 1.98 \mathrm{~b}^{\mathrm{a}}$ & $9.17 \pm 1.64 \mathrm{a}^{\mathrm{c}}$ & $19.81 \pm 1.42 \mathrm{c}^{\mathrm{b}}$ & $403.09 \pm 20.15 c^{a}$ \\
\hline \multirow{2}{*}{$\mathrm{CHM}$} & Low & $3.14 \pm 0.25 \mathrm{a}^{\mathrm{c}}$ & $7.39 \pm 0.70 \mathrm{a}^{\mathrm{b}}$ & $10.94 \pm 2.36 b^{a}$ & $8.56 \pm 0.43 \mathrm{a}^{\mathrm{c}}$ & $37.34 \pm 3.49 \mathrm{a}^{\mathrm{b}}$ & $507.21 \pm 29.27 \mathrm{~b}^{\mathrm{a}}$ \\
\hline & High & $3.90 \pm 0.15 \mathrm{a}^{\mathrm{c}}$ & $7.05 \pm 0.71 \mathrm{a}^{\mathrm{b}}$ & $18.10 \pm 1.72 \mathrm{a}^{\mathrm{a}}$ & $8.97 \pm 0.72 \mathrm{a}^{\mathrm{c}}$ & $42.86 \pm 5.58 \mathrm{a}^{\mathrm{b}}$ & $737.83 \pm 82.58 \mathrm{a}^{\mathrm{a}}$ \\
\hline
\end{tabular}

DOM: stands for dissolved organic matter; COF: represents commercial organic fertilizer; COM: cow manure; CHM: chicken manure; $\mathrm{Pb} 0, \mathrm{~Pb} 100$ and $\mathrm{Pb} 800$ denote the pot soils to which 0,100 and $800 \mathrm{mg} \cdot \mathrm{kg}^{-1} \mathrm{~Pb}$ were added, respectively. The different superscript letters in the same row indicate significant difference in $\mathrm{Pb}$ concentrations $(p<0.05)$ among the soil Pb levels according to the LSD (Least Significant Difference) test. The different letters following the data in the same column indicate significant difference in $\mathrm{Pb}$ concentrations $(p<0.05)$ among DOM treatments according to the LSD test. Data are means \pm SE $(n=3)$.

Irrespective of DOM sources, $\mathrm{Pb}$ concentrations varied $3.70-7.42 \mathrm{mg} \cdot \mathrm{kg}^{-1}, 7.34-10.74 \mathrm{mg} \cdot \mathrm{kg}^{-1}$ and $11.06-24.95 \mathrm{mg} \cdot \mathrm{kg}^{-1}$ for DOM-free treatment, low dosage DOM and high dosage DOM, respectively, in shoots (edible parts) of B. chinensis grown in $800 \mathrm{mg} \cdot \mathrm{kg}^{-1}$ soil (Figure 1). This 
indicated that high dosage DOM treatment increased $\mathrm{Pb}$ concentrations in edible part of B. chinensis grown in the soil with high $\mathrm{Pb}$ level.

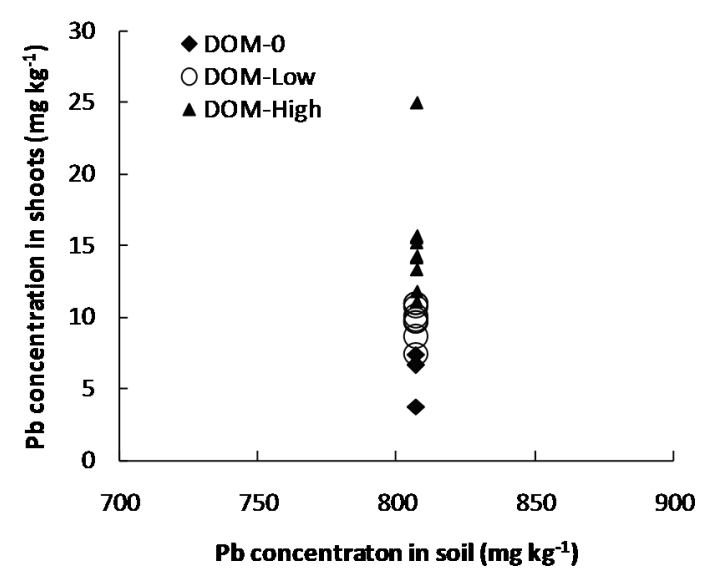

Figure 1. $\mathrm{Pb}$ concentrations in shoots of Brassica chinensis for different DOM (dissolved organic matter) levels. DOM-0, DOM-Low and DOM-High indicate DOM-free treatment, low dosage DOM treatment and high dosage DOM treatment, respectively.

\subsection{Translocation of Pb from Soil to Shoots}

Basically consistent with the shoot $\mathrm{Pb}$ concentrations, translocation factor of $\mathrm{Pb}$ was the highest in the B. chinensis grown in the $\mathrm{Pb} 800$ soil applied with the high $\mathrm{DOM}_{\mathrm{CHM}}$ treatment, and there was no significant difference between the DOM treatment and the controls at the Pb0, P100 and Pb800 levels (Table 4). Expectedly, the translocation factor of $\mathrm{Pb}$ decreased sharply with the increase of soil $\mathrm{Pb}$ level, showing significant differences between different soil $\mathrm{Pb}$ levels at the same DOM source or dosage.

Table 4. Translocation factor of $\mathrm{Pb}$ from soil to shoots of Brassica chinensis (shoots/soil) treated with varying amounts of $\mathrm{DOM}$ from different sources at different soil $\mathrm{Pb}$ levels.

\begin{tabular}{ccccc}
\hline \multirow{2}{*}{ DOM Source } & \multirow{2}{*}{ DOM Dosage } & \multicolumn{3}{c}{ Pb Translocation Factor } \\
\cline { 3 - 5 } & & Pb0 & Pb100 & Pb800 \\
\hline \multirow{2}{*}{ control } & 0 & $0.57 \pm 0.04 \mathrm{a}^{\mathrm{a}}$ & $0.063 \pm 0.002 \mathrm{a}^{\mathrm{b}}$ & $0.009 \pm 0.003 \mathrm{~b}^{\mathrm{c}}$ \\
\hline \multirow{2}{*}{ COF } & Low & $0.65 \pm 0.25 \mathrm{a}^{\mathrm{a}}$ & $0.063 \pm 0.003 \mathrm{a}^{\mathrm{b}}$ & $0.013 \pm 0.002 \mathrm{~b}^{\mathrm{c}}$ \\
& High & $0.54 \pm 0.08 \mathrm{a}^{\mathrm{a}}$ & $0.080 \pm 0.016 \mathrm{a}^{\mathrm{b}}$ & $0.016 \pm 0.002 \mathrm{ab}^{\mathrm{c}}$ \\
\hline \multirow{2}{*}{$\mathrm{COM}$} & Low & $0.52 \pm 0.10 \mathrm{a}^{\mathrm{a}}$ & $0.069 \pm 0.004 \mathrm{a}^{\mathrm{b}}$ & $0.012 \pm 0.001 \mathrm{~b}^{\mathrm{c}}$ \\
& High & $0.54 \pm 0.03 \mathrm{a}^{\mathrm{a}}$ & $0.072 \pm 0.012 \mathrm{a}^{\mathrm{b}}$ & $0.015 \pm 0.002 \mathrm{ab}^{\mathrm{c}}$ \\
\hline \multirow{2}{*}{$\mathrm{CHM}$} & Low & $0.44 \pm 0.02 \mathrm{a}^{\mathrm{a}}$ & $0.069 \pm 0.007 \mathrm{a}^{\mathrm{b}}$ & $0.014 \pm 0.003 \mathrm{ab}^{\mathrm{c}}$ \\
& High & $0.55 \pm 0.09 \mathrm{a}^{\mathrm{a}}$ & $0.066 \pm 0.003 \mathrm{a}$ & $0.022 \pm 0.003 \mathrm{a}^{\mathrm{c}}$ \\
\hline
\end{tabular}

DOM: stands for dissolved organic matter; COF: represents commercial organic fertilizer; COM: cow manure; CHM: chicken manure; Pb0, Pb100 and Pb800 denote the pot soils to which 0,100 and $800 \mathrm{mg} \cdot \mathrm{kg}^{-1} \mathrm{~Pb}$ were added, respectively. The different superscript letters in the same row indicate significant difference in $\mathrm{Pb}$ translocation factor $(p<0.05)$ among the soil Pb levels according to the LSD (Least Significant Difference) test. The different letters following the data in the same column indicate significant difference in $\mathrm{Pb}$ translocation factor $(p<0.05)$ among DOM treatments according to the LSD test. Data are means \pm SE $(n=3)$.

\subsection{Specific Lead Uptake}

Apparently, specific lead uptake of $B$. chinensis was appreciably enhanced in the $\mathrm{DOM}_{\mathrm{CHM}}$ treatments at all the three soil $\mathrm{Pb}$ levels, with a statistically significant difference between the high $\mathrm{DOM}_{\mathrm{CHM}}$ treatment and the control at the Pb800 level $(p<0.001)$ (Figure 2c). There was no significant increase in SLU for $\mathrm{DOM}_{\mathrm{COF}}$ and $\mathrm{DOM}_{\mathrm{COM}}$ treatments relative to the controls at the three soil $\mathrm{Pb}$ 
levels (Figure 2a,b). As expected, SLU displayed an increasing trend with the increase of soil Pb level for the same DOM treatment (Figure 2).

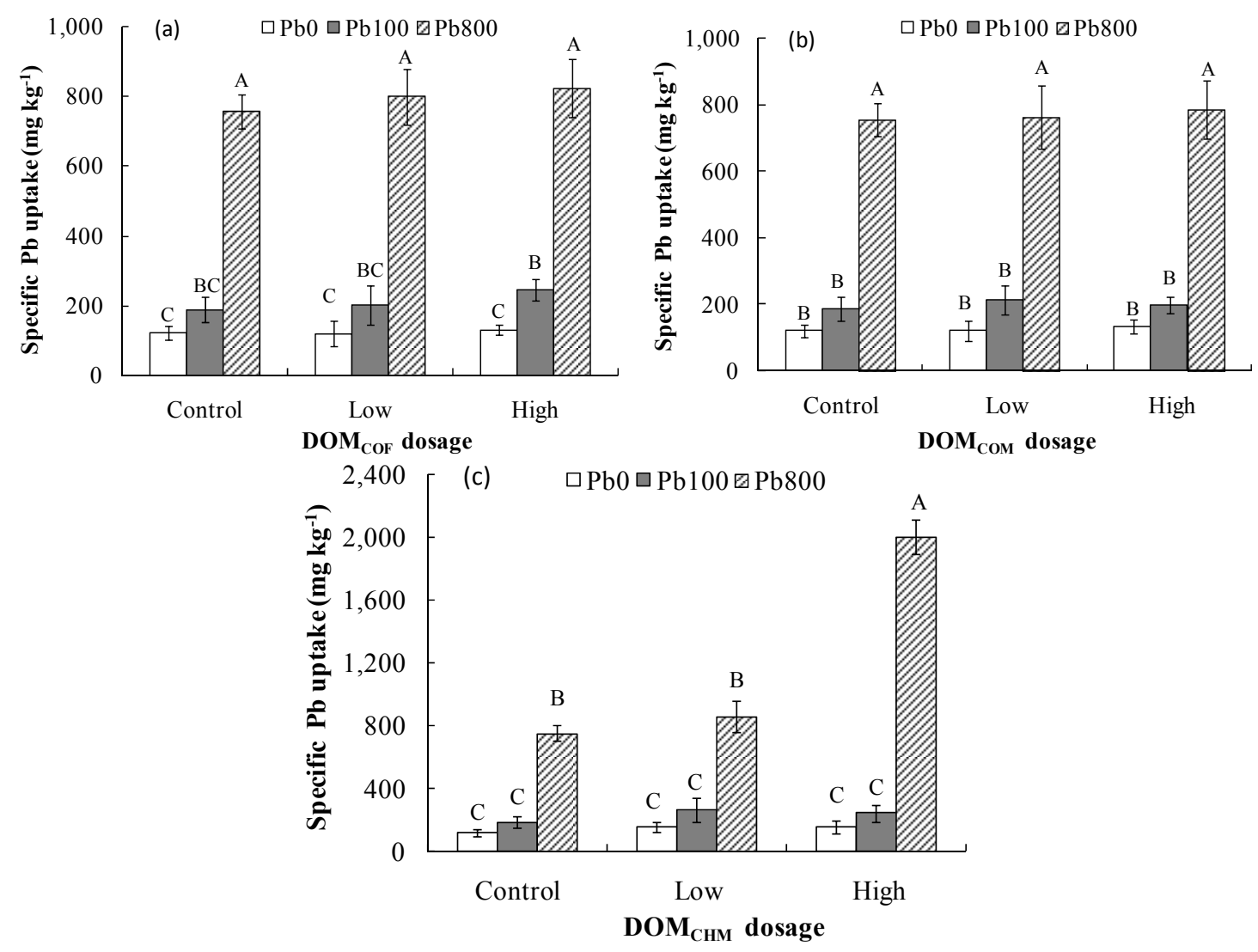

Figure 2. Specific lead uptake by root of Brassica chinensis under different addition dosage of DOM (dissolved organic matter) derived from: commercial organic fertilizer (a); cow manure (b); and chicken manure (c). The different capital letters above the bars indicated significant difference $(p<0.01)$ among $\mathrm{Pb}$ levels and different DOM Level based on the Least Significant Difference test. Data are means $\pm \mathrm{SE}$ $(n=3)$.

\subsection{Potential Health Risks of $\mathrm{Pb}$}

The daily consumption of vegetables is estimated to be 345 and $231.5 \mathrm{~g}$. person ${ }^{-1}$. day $^{-1}$ for adult and children inhabitants of urban areas of Tianjin city, respectively $[25,26]$. In this study, $300 \mathrm{~g}$. person ${ }^{-1}$. day ${ }^{-1}$ was chosen as the average amount of $B$. chinensis daily consumed by Nanjing inhabitants. According to the Nanjing Bureau of Statistics, the population of Nanjing City in 2015 was 8.24 million [27]. The estimated increase of the amount of $\mathrm{Pb}$ ingested by the population of Nanjing City is shown in Table 5.

It can be seen from Table 5 that the total increase in the amount of $\mathrm{Pb}$ ingested by the inhabitants of Nanjing City in a year due to the application of DOM could potentially be in the range of 2018-9640 kg. The degree of increase in the amount of $\mathrm{Pb}$ ingested depended on both the source and the amount of DOM added to the soil. The $\mathrm{DOM}_{\mathrm{CHM}}$ treatment showed the greatest increase in the amounts of $\mathrm{Pb}$ ingested. 
Table 5. Estimated increase in the amount of $\mathrm{Pb}$ ingested through vegetable consumption due to the increased concentration in the edible parts of Brassica chinensis resulting from the addition of DOM to the soil.

\begin{tabular}{ccccccc}
\hline \multirow{2}{*}{ Amount of $\mathbf{P b}$} & \multicolumn{2}{c}{ COF } & \multicolumn{2}{c}{ COM } & \multicolumn{2}{c}{ CHM } \\
\cline { 2 - 7 } & Low & High & Low & High & low & High \\
\hline$I_{p}(\%)$ & 44 & 112 & 30 & 59 & 47 & 144 \\
$I_{a}(\mathrm{~kg})$ & 2974 & 5287 & 2018 & 3943 & 3174 & 9640 \\
\hline
\end{tabular}

DOM: stands for dissolved organic matter; COF: represents commercial organic fertilizer; COM: cow manure; CHM: chicken manure; $I_{p}=\left(C_{d o m}-C\right) / C \times 100 ; C_{d o m}$ is the $\mathrm{Pb}$ concentration in the edible parts of Brassica chinensis when DOM is added to the soil; $C$ is the $\mathrm{Pb}$ concentration $\left(7.42 \mathrm{mg} \cdot \mathrm{kg}^{-1}\right)$ in edible part of Brassica chinensis grown in $800 \mathrm{mg} \cdot \mathrm{kg}^{-1} \mathrm{~Pb}$ soil without DOM added.

\section{Discussion}

The present study indicates that the effect of $\mathrm{DOM}$ on $\mathrm{Pb}$ uptake and translocation in B. chinensis is dependent on source and dosage of $\mathrm{DOM}$, and $\mathrm{Pb}$ concentration in soil. It has been recognized that $\mathrm{Pb}$ solubility and mobility in soil depend on its chemical speciation and that dissolved forms and exchangeable forms of $\mathrm{Pb}$ in soil are readily available to plants [5]. $\mathrm{Pb}$ is prone to complex with $\mathrm{DOM}$ and the formation of organo-metallic complexes can increase the solubility and decrease the adsorption of $\mathrm{Pb}$, resulting in an increase in $\mathrm{Pb}$ bioavailability and eventually $\mathrm{Pb}$ uptake by plants $[5,28-30]$.

The increased $\mathrm{Pb}$ concentrations in roots of $B$. chinensis grown in the soils applied with $\mathrm{DOM}_{\mathrm{CHM}}$ (Table 3) could be attributed to the formation of organo- $\mathrm{Pb}$ complexes between $\mathrm{DOM}_{\mathrm{CHM}}$ molecules and $\mathrm{Pb}$ and thereby enhanced $\mathrm{Pb}$ bioavailability in soil. Increased root $\mathrm{Pb}$ concentration was also observed for high $\mathrm{DOM}_{\mathrm{COF}}$ and $\mathrm{DOM}_{\mathrm{COM}}$ treatments at the $\mathrm{Pb} 0$ level, but not at the $\mathrm{Pb} 100$ and $\mathrm{Pb} 800$ levels (Table 3). The observation can be explained by the following reasons. The original $\mathrm{Pb}$ in the $\mathrm{Pb} 0$ soil is considered to be less soluble and mobile than the lately added $\mathrm{Pb}$ in the $\mathrm{Pb} 100$ and $\mathrm{Pb} 800$ soils. The high $\mathrm{DOM}_{\mathrm{COF}}$ and $\mathrm{DOM}_{\mathrm{COM}}$ treatments could have improved the bioavailability of original $\mathrm{Pb}$ in the $\mathrm{Pb} 0$ soil by forming soluble organo- $\mathrm{Pb}$ complexes. By contrast, the lately-added $\mathrm{Pb}$ in the $\mathrm{Pb} 100$ and $\mathrm{Pb} 800$ soils remained highly available to plants and the presence of $\mathrm{DOM}_{\mathrm{COF}}$ and $\mathrm{DOM}_{\mathrm{COM}}$, which were much lower in TOC concentration than $\mathrm{DOM}_{\mathrm{CHM}}$, had no positive effect on the already high bioavailability of $\mathrm{Pb}$ in the $\mathrm{Pb} 100$ and $\mathrm{Pb} 800$ soils. The TOC concentrations of these DOM samples differed greatly: $6605 \mathrm{mg} \cdot \mathrm{L}^{-1}$ for $\mathrm{DOM}_{\mathrm{CHM}}, 13$ times higher than that for $\mathrm{DOM}_{\mathrm{COM}}$ and 95 times higher than that for $\mathrm{DOM}_{\mathrm{COF}}$ (Table 1). The increased root $\mathrm{Pb}$ concentration for all the $\mathrm{DOM}_{\mathrm{CHM}}$ treatments across the three soil Pb levels could be partially attributed to the much higher TOC concentration in $\mathrm{DOM}_{\mathrm{CHM}}$. It has been reported that the degree of complexation between $\mathrm{Pb}$ and DOM increases with the increase of DOM concentration [5,12]. Inaba and Takenaka [31] showed that the amount of $\mathrm{Cu}$ taken up by the plants was related to the concentration of organic acid. Antoniadis and Alloway [32] also reported that an increase in DOM concentration increased metal uptake by plants. However, in the present study, the effects of $\mathrm{DOM}_{\mathrm{COF}}$ and $\mathrm{DOM}_{\mathrm{COM}}$ on $\mathrm{Pb}$ concentrations in B. chinensis were not significantly different despite the six-fold difference in TOC concentrations between them. The effect of DOM on bioavailability of heavy metals depends not only on quantity (concentration) but also quality (composition) of DOM [31,33-35]. The increased root $\mathrm{Pb}$ concentration for all the DOM $\mathrm{CHM}_{\mathrm{CH}}$ treatments might also be attributable to the composition of $\mathrm{DOM}_{\mathrm{CHM}}$. Further mechanistic studies at lab and greenhouse levels are required to clarify the reason for these results.

Increased shoot $\mathrm{Pb}$ concentration was observed in the B. chinensis grown in the $\mathrm{Pb} 800$ soil applied with high DOM, especially for high $\mathrm{DOM}_{\mathrm{CHM}}$. Given the significantly decreased biomass of shoots and roots of B. chinensis and blackened roots (data not shown) in the high $\mathrm{DOM}_{\mathrm{CHM}}$ treatment, the increased shoot $\mathrm{Pb}$ concentration might be attributable to the concentration effect of the decreased shoot biomass and/or enhanced $\mathrm{Pb}$ translocation to shoots due to damaged roots for the high $\mathrm{DOM}_{\mathrm{CHM}}$ treatment. The significant increases in translocation factor of $\mathrm{Pb}$ and SLU for the high $\mathrm{DOM}_{\mathrm{CHM}}$ treatment (Table 4, Figure 2) might be explained for the same reason. The decreased biomass in the 
high $\mathrm{DOM}_{\mathrm{CHM}}$ treatment could be caused by the $\mathrm{Pb}$ toxicity to $\mathrm{B}$. chinensis, which might be somehow enhanced after the addition of high $\mathrm{DOM}_{\mathrm{CHM}}$ because $\mathrm{DOM}_{\mathrm{CHM}}$ or high-level $\mathrm{Pb}$ alone had no adverse effect on the growth of $B$. chinensis as indicated in the $\mathrm{Pb} 0$ soil applied with high $\mathrm{DOM}_{\mathrm{CHM}}$ and the $\mathrm{Pb} 800$ control, respectively (Table 2).

Traditionally, large quantities of organic fertilizers are applied to vegetable soil to improve soil physico-chemical properties [36,37]. For example, $90-105 \mathrm{t} \cdot \mathrm{hm}^{-2} \cdot \mathrm{a}^{-1}$ of organic fertilizer was applied to soil used to grow vegetables in Shenyang city, Liaoning province, China, $80 \%$ of which was chicken mature [38]. Though organic fertilizer can increase vegetable growth and production, it may also increase uptake and translocation of heavy metals in vegetables and may potentially pose a risk to public health due to the consumption of these vegetables. In the present study, the increase of the amount of $\mathrm{Pb}$ ingested by the population was estimated based on the present data and population of Nanjing City in 2015. Under the condition of DOM application, the annual increase of the amount of $\mathrm{Pb}$ ingested by the population of Nanjing City could potentially be $2018-9640 \mathrm{~kg}$, because of consumption of $B$. chinensis grown in $\mathrm{Pb}$ polluted soil.

Unexpectedly, with the exception of the high $\mathrm{DOM}_{\mathrm{CHM}}$ treatment in the $\mathrm{Pb} 800$ soil, in which B. chinensis displayed increased $\mathrm{Pb}$ concentration in shoots due to $\mathrm{Pb}$ toxicity, it is generally indicated in the present study that $\mathrm{Pb}$ concentration in edible shoots part of $B$. chinensis under normal growth was not significantly influenced by the application of DOM of various sources differing greatly in TOC concentration at different soil $\mathrm{Pb}$ levels, despite that $\mathrm{Pb}$ concentration in roots was enhanced in some DOM treatments. The result suggests that as far as DOM is concerned, the risk of $\mathrm{Pb}$ pollution of B. chinensis by the presence of DOM in soil originated from these organic fertilizers could be negligible. On the other hand, the application of $\mathrm{DOM}$, in particular, $\mathrm{DOM}_{\mathrm{CHM}}$, did increase $\mathrm{Pb}$ concentration in roots of $B$. chinensis in some treatments as indicated in the present study. The risk can rise that $\mathrm{Pb}$ accumulated in roots may be translocated to shoots under some conditions as seen in the high $\mathrm{DOM}_{\mathrm{CHM}}$ treatment in Pb800 soil. It should be noted that the present study used only DOM extracts from some organic fertilizers, and in practice, enhanced presence of DOM occurs in soils incorporated with organic fertilizers. Further experiments at glasshouse and field levels considering practical conditions associated with organic fertilization in vegetable production are needed to understand the effect of DOM derived from various organic fertilizers on $\mathrm{Pb}$ uptake, translocation and pollution risk of $\mathrm{Pb}$ in B. chinensis and other vegetables.

\section{Conclusions}

Effect of DOM on uptake and translocation of $\mathrm{Pb}$ in B. chinensis depended on DOM sources, $\mathrm{DOM}$ dosage and $\mathrm{Pb}$ pollution level. $\mathrm{DOM}_{\mathrm{CHM}}$ significantly increased $\mathrm{Pb}$ concentrations in roots of B. chinensis grown in the low and high $\mathrm{Pb}$ soils, while $\mathrm{DOM}_{\mathrm{COF}}$ and $\mathrm{DOM}_{\mathrm{COM}}$ at low dosage had no significant effect on root $\mathrm{Pb}$ concentration in the low $\mathrm{Pb}$ soil. There was no significant increase in shoot $\mathrm{Pb}$ concentration for all the DOM treatments except the high $\mathrm{DOM}_{\mathrm{CHM}}$ treatment in the soil with $800 \mathrm{mg} \cdot \mathrm{kg}^{-1} \mathrm{~Pb}$. Consistent with the $\mathrm{Pb}$ concentrations in shoots, translocation factor of $\mathrm{Pb}$ from soil to shoot was higher for the high $\mathrm{DOM}_{\mathrm{CHM}}$ treatment than for other DOM treatments. Apparently, the application of $\mathrm{DOM}_{\mathrm{CHM}}$ as well as $\mathrm{DOM}_{\mathrm{COF}}$ and $\mathrm{DOM}_{\mathrm{COM}}$ at high dosage increased the SLU by $B$. chinensis, showing a statistically significant increase for the high $\mathrm{DOM}_{\mathrm{CHM}}$ treatment in the high $\mathrm{Pb}$ soil. The application of DOM to the soil with $800 \mathrm{mg} \cdot \mathrm{kg}^{-1} \mathrm{~Pb}$ could result in an increase in total $\mathrm{Pb}$ annually ingested by the inhabitants of Nanjing City in the range of 2018-9640 kg, with the highest estimates resulting from the high $\mathrm{DOM}_{\mathrm{CHM}}$ treatment. This study suggests that as far as DOM is concerned, the risk of $\mathrm{Pb}$ pollution of $B$. chinensis by enhanced presence of DOM due to organic fertilization could be negligible. On the other hand, the risk may rise that $\mathrm{Pb}$ accumulated in roots could be translocated to shoots under some conditions as indicated in high DOM $\mathrm{CHM}_{\text {treatment }}$ and high $\mathrm{Pb}$ pollution level.

Acknowledgments: This work was supported by the Natural Science Foundation of Jiangsu Province (BK20141479), Jiangsu Key Laboratory of Agricultural Meteorology (KYQ1402), the Natural Science Foundation 
of China (41001190), State Key Laboratory of Soil and Sustainable Agriculture (Institute of Soil Science, Chinese Academy of Sciences) (Y052010018) and National Major Science and Technology Program for Water Pollution Control and Treatment (2015ZX07204-002-003).

Author Contributions: Renying Li designed the study; Renying Li, Xiaojin Xie and Yingxue Li carried out the experiments; Renying Li and Zhigao Zhou wrote the first draft; Yaohong Zhang and Xianghua Xu assisted with data analysis, mostly in charge of tables and figures.

Conflicts of Interest: The authors declare no conflict of interest.

\section{References}

1. Gupta, D.K.; Nicoloso, F.T.; Schetinger, M.R.C.; Rossato, L.V.; Pereira, L.B.; Castro, G.Y.; Srivastava, S.; Tripathi, R.D. Antioxidant defense mechanism in hydroponically grown Zea mays seedlings under moderate lead stress. J. Hazard. Mater. 2009, 172, 479-484. [CrossRef] [PubMed]

2. Sengar, R.S.; Gautam, M.; Sengar, R.S.; Garg, S.K.; Sengar, K.; Chaudhary, R. Lead stress effects on physiobiochemical activities of higher plants. Rev. Environ. Contam. Toxicol. 2008, 196, 73-93. [PubMed]

3. Sharma, P.; Dubey, R.S. Lead toxicity in plants. Braz. J. Plant Physiol. 2005, 17, 35-52. [CrossRef]

4. Li, T.Q.; Tao, Q.; Liang, C.F.; Shohag, M.J.I.; Yang, X.E.; Sparks, D.L. Complexation with dissolved organic matter and mobility control of heavy metals in the rhizosphere of hyperaccumulator Sedum alfredii. Environ. Pollut. 2013, 182, 248-255. [CrossRef] [PubMed]

5. Shahid, M.; Pinelli, E.; Dumat, C. Review of Pb availability and toxicity to plants in relation with metal speciation; role of synthetic and natural organic ligands. J. Hazard. Mater. 2012, 219-220, 1-12. [CrossRef] [PubMed]

6. Miller, G.; Begonia, G.; Begonia, M.; Ntoni, J. Bioavailability and Uptake of Lead by Coffeeweed (Sesbania exaltata Raf.). Int. J. Environ. Res. Public Health 2008, 5, 436-440. [CrossRef] [PubMed]

7. Ashworth, D.J.; Alloway, B.J. Influence of dissolved organic matter on the solubility of heavy metals in sewage-sludge-amended soils. Commun. Soil Sci. Plant Anal. 2008, 39, 538-550. [CrossRef]

8. Jordan, R.N.; Yonge, D.R.; Hathhom, W.E. Enhanced mobility of $\mathrm{Pb}$ in the presence of dissolved natural organic matter. J. Contam. Hydrol. 1997, 29, 59-80. [CrossRef]

9. Khan, S.; Cao, Q.; Chen, B.D.; Zhu, Y.G. Humic acids increase the phytoavailability of Cd and Pb to wheat plants cultivated in freshly spiked, contaminated soil. J. Soil Sediment. 2006, 6, 236-242.

10. Tam, N.F.Y.; Wong, Y.S. Spent litter as fertilizer for growing vegetables. Bioresour. Technol. 1995, 53, 151-155. [CrossRef]

11. Zhou, D.M.; Hao, X.Z.; Wang, Y.J.; Dong, Y.H.; Cang, L. Copper and Zn uptake by radish and pakchoi as affected by application of livestock and poultry manures. Chemosphere 2005, 59, 167-175. [CrossRef] [PubMed]

12. Pérez-Esteban, J.; Escolástico, C.; Masaguer, A.; Vargas, C.; Moliner, A. Soluble organic carbon and pH of organic amendments affect metal mobility and chemical speciation in mine soils. Chemosphere 2014, 103, 164-171. [CrossRef] [PubMed]

13. Wang, Z.X.; Qu, M. Dissolved organic matter and its effect on activity of soil heavy metal. Chin. Agric. Sci. Bull. 2005, 21, 388-392. (In Chinese)

14. Song, X.J. The status quo and the appropriate technical measures for the utilization of organic fertilizers in China. Rural Eco-Environ. 1997, 13, 56-59. (In Chinese)

15. Yang, F.; Li, R.; Cui, Y.; Duan, Y.H. Utilization and develop strategy of organic fertilizer resources in China. Soils Fertil. Sci. China 2010, 4, 77-82. (In Chinese)

16. Warman, P.R.; Cooper, J.M. Fertilization of a mixed forage crop with fresh and composted chicken manure and NPK fertilizer: Effects on soil and tissue Ca, Mg, S, B, Cu, Fe, Mn and Zn. Can. J. Soil Sci. 2000, 80, 345-352. [CrossRef]

17. Wang, G.; Su, M.Y.; Chen, Y.H.; Lin, F.F.; Luo, D.; Gao, S.F. Transfer characteristics of cadmium and lead from soil to the edible parts of six vegetable species in southeastern China. Environ. Pollut. 2006, 144, 127-135. [CrossRef] [PubMed]

18. Zhou, H.; Yang, W.T.; Zhou, X.; Liu, L.; Gu, J.F.; Wang, W.L.; Zou, J.L.; Tian, T.; Peng, P.Q.; Liao, B.H. Accumulation of Heavy Metals in Vegetable Species Planted in Contaminated Soils and the Health Risk Assessment. Int. J. Environ. Res. Public Health 2016, 13, 289. [CrossRef] [PubMed] 
19. Cui, Y.L.; Zhu, Y.G.; Zhai, R.H.; Chen, D.Y.; Huang, Y.Z.; Qiu, Y.; Liang, J.Z. Transfer of metals from soil to vegetables in an area near a smelter in Nanning, China. Environ. Int. 2004, 30, 785-791. [CrossRef] [PubMed]

20. Twining, J.R.; Payne, T.E.; Itakura, T. Soil-water distribution coefficients and plant transfer factors for ${ }^{134}$ Cs, ${ }^{85} \mathrm{Sr}$ and ${ }^{65} \mathrm{Zn}$ under field conditions in tropical Australia. J. Environ. Radioact. 2004, 71, 71-87. [CrossRef]

21. Lu, R.K. Analytical Methods for Soils and Agricultural Chemistry; China Agricultural Science and Technology Press: Beijing, China, 1999.

22. Nelson, D.W.; Sommers, L.E. Total carbon, organic carbon and organic matter. In Methods of Soil Analysis, Part 2-Chemical and Microbiological Properties, 2nd ed.; Page, A.L., Miller, R.H., Keeney, D.R., Eds.; ASA-SSSA: Madison, WI, USA, 1982; pp. 403-430.

23. Barricuso, E.; Bear, U.; Calvet, R. Dissolved organic matter and adsorption-desorption of Dimefuron, Atrazine and Carbetamide by soils. J. Environ. Qual. 1992, 21, 737-751.

24. Liu, W.J.; Zhu, Y.G.; Smith, F.A. Effects of iron and manganese plaques on arsenic uptake by rice seedlings (Oryza sativa L.) grown in solution culture supplied with arsenate and arsenite. Plant Soil 2005, 277, 127-138. [CrossRef]

25. Dong, Q.N.; Wu, J.H.; Jia, M. An analysis of meals nutrients of children below 14 years old in Tianjin. Chin. J. Prevent. Control Chronic Dis. 1998, 3, 138-139. (In Chinese)

26. Wang, X.; Yang, X.L.; Hu, G.; Dong, Q.N.; Nan, Y.; Tian, H.G. An assessment on meals of the general public in Tianjin, 1992. Chin. J. Prevent. Control Chronic Dis. 1996, 4, 18-21. (In Chinese)

27. Nanjing Municipal Bureau of Statistics (2016). Nanjing 2015 Statistical Bulletin for National Economic and Social Development; Nanjing Municipal Bureau of Statistics: Nanjing, China, 2015.

28. Kim, K.R.; Owens, G.; Naidu, R.; Kwon, S.I. Influence of plant roots on rhizosphere soil solution composition of long-term contaminated soils. Geoderma 2010, 155, 86-92. [CrossRef]

29. Li, R.Y.; Zhou, Z.G.; Yue, H.Y.; Zhu, H.X.; Xie, X.J. Effect of Dissolved Organic Matter on Adsorption-desorption of $\mathrm{Pb}$ in the Vegetable Soil from a Suburb of Nanjing, China. J. Agro-Environ. Sci. 2011, 30, 867-873. (In Chinese)

30. Sahi, S.V.; Bryant, N.L.; Sharma, N.C.; Singh, S.R. Characterization of a lead hyperaccumulator shrub. Sesbania Drummondii. Environ. Sci. Technol. 2002, 36, 4676-4680. [CrossRef] [PubMed]

31. Inaba, S.; Takenaka, C. Effects of dissolved organic matter on toxicity and bioavailability of copper for lettuce sprouts. Environ. Int. 2005, 31, 603-608. [CrossRef] [PubMed]

32. Antoniadis, V.; Alloway, B.J. The role of dissolved organic carbon in themobility of Cd, Ni and $\mathrm{Zn}$ in sewage sludge-amended soils. Environ. Pollut. 2002, 117, 515-521. [CrossRef]

33. Wang, X.D.; Chen, X.N.; Liu, S.; Ge, X.Z. Effect of molecular weight of dissolved organic matter on toxicity and bioavailability of copper to lettuce. J. Environ. Sci. 2010, 22, 1960-1965. [CrossRef]

34. Liang, B.G.; Gregorich, E.G.; Schnitzer, M.; Schulten, H.R. Characterization of water extracts of two manures and their adsorption on soils. Soil Sci. Soc. Am. J. 1996, 60, 1758-1763. [CrossRef]

35. Li, Z.G.; Bian, C.Z.; Jie, X.L. Characteristic of Cd sorption in the copper tailings wasteland soil by amended dissolved organic matter from fresh manure and manure compost. Afr. J. Biotech. 2007, 6, 227-234.

36. Chen, L.; Dick, W.A.; Streeter, J.G.; Hoitink, H.A.J. Ryegrass utilization of nutrients released from composted biosolids and cow manure. Compost Sci. Util. 1996, 4, 73-83. [CrossRef]

37. Guisquiani, P.L.; Pagliai, M.; Gigliotti, G.; Benetti, A. Urban waste compost: effects on physical, chemical, and biochemical soil properties. J. Environ. Qual. 1995, 24, 175-182. [CrossRef]

38. Jiang, Y.; Liang, W.J.; Wen, D.Z.; Zhang, Y.G.; Chen, W.B. Spatial heterogeneity of DTPA-extractable zinc in cultivated soils induced by city pollution and land use. Sci. China Ser. C Life Sci. 2005, 48, 82-91.

(C) 2016 by the authors; licensee MDPI, Basel, Switzerland. This article is an open access article distributed under the terms and conditions of the Creative Commons Attribution (CC-BY) license (http://creativecommons.org/licenses/by/4.0/). 